Original Article

\title{
Seasonal Variation of Appendicitis in High Altitude Region of Nepal: Five years' Experience of a Teaching Hospital
}

Suryaman Menyangbo ${ }^{1}$, Gakul Bhatta ${ }^{1}$, Harihar Devkota ${ }^{1}$, Manik Neupane ${ }^{1}$, Poojan Rokaya ${ }^{1}$, Prem Prasad Panta ${ }^{2}$

${ }^{1}$ Assistant professor, ${ }^{2}$ Associate professor, Karnali academy of health sciences, Jumla Nepal

Corresponding author:

Dr. Suryaman Menyangbo; Head of Department of General surgery,

Email: suryaman77@gmail.com

\section{ABSTRACT}

Background: Acute appendicitis is the most common general surgical disease, worldwide. The exact etiology is still in conjecture. However, the inadequate fiber in diet, smoking, mechanical obstruction in appendiceal lumen, has been attributed as factors for appendicitis. Appendicitis presents throughout months of the year, however, incidence increases in particular months. The objective of this study is to observe the appendicitis incidence variation with months of the year in high altitude region of Nepal.

Methods: The cross-sectional retrospective study was conducted in the Karnali Academy of Health Sciences, Jumla situated at the altitude above $2500 \mathrm{~m}$ from sea level. The clinical data were retrieved from the hospital record book in the Operation Theater that included age, gender, ethnicity, month of the appendectomy executed, pre-operative clinical presentation, and operative findings. The period of study was from July 2014 to March 2020. The data were entered in Microsoft Excel software and descriptive analysis was done to get mean, median percentage, standard deviation by SPSS 16.

Results: A total of 119 appendectomies performed during 5 years period, from 2014 to 2020, in the surgery department of Karnali Academy of Health Sciences were recorded. The mean age of appendectomy was 27 years. There were $53 \%$ female $(n=64)$ and $46 \%$ male $(n=55)$ patients. The months in which the highest appendectomy executed were July/August/September and February with 16\% (n=19), 13.4\% (n=16), (n=15) $12.6 \%$ and $13.4 \%(n=16)$ respectively. The lowest incidence was $1.7 \%$ in the month of April.

Conclusion: The incidence of appendicitis is high in the months from July to September with the lowest incidence is in the months of April and May. This information could be useful to decrease the diseaseassociated morbidity and mortality as well as it can be useful for hospital administration for enrolling the needed health-workers in those particular time periods.

Keywords: Appendicitis, Altitude, Seasons variation, Meteorology

\begin{tabular}{|c|c|c|}
\hline \multicolumn{2}{|c|}{ Access this article Online } & ArticleInfo. \\
\hline Quick Response Code & Website: & How to cite this article in Vancouver Style? \\
\hline & www.jkahs.org.np & $\begin{array}{l}\text { Menyangbo S, Bhatta G, Devkota H, Neupane } \\
\text { M, Rokaya P, Panta PP. Seasonal Variation of } \\
\text { Appendicitis in High Altitude Region of } \\
\text { Nepal: Five years' Experience of a Teaching } \\
\text { Hospital. Karnali Academy of Health Sciences } \\
\text { 2020;3(1):1-8. }\end{array}$ \\
\hline & $\begin{array}{l}\text { DOI: } \\
\text { https://doi.org/10.3126/jkahs.v3i1.28843 } \\
\text { The DOI will be functional after the } \\
\text { issue is fully published online as well as } \\
\text { in printed version }\end{array}$ & $\begin{array}{l}\text { Received: } 12 \text { March. } 2020 \\
\text { Accepted: } 29 \text { April, } 2020 \\
\text { Published Online: } 1 \text { May. } 2020 \\
\text { Conflict of Interest: None } \\
\text { Source of Support: None }\end{array}$ \\
\hline
\end{tabular}




\section{INTRODUCTION}

Acute appendicitis is the most common general surgical emergency worldwide with life time risk for appendectomy 7.5 to $12 \%$, commonly occurring in adolescent and young adults. $^{1,2}$ The etiology of the appendicitis is still obscure and multifactorial. The disease has been attributed to a multiple causes which include inadequate fiber $\operatorname{diet}^{3}$, smoking ${ }^{4}$, mechanical obstruction of appendiceal lumen, radiation, sanitation, bacterial, viral and parasitic infestation ${ }^{5,6}$.There are some evidences that shows appendicitis vary with climates seasons. ${ }^{7}$ Appendicitis presents throughout different month of the year, however, incidence increases is higher in particular months. ${ }^{8}$ There are many disparities in the incidence of acute appendicitis. Several studies have been done to assess the seasonal variation of acute appendicitis with variable result. ${ }^{9}$ However, Some authors reported high incidence of the cases in the summer month. $^{10,11}$

Although several epidemiological studies on appendicitis have been conducted, most have based on western and European population, with relatively fewer epidemiological studies have based on south Asian population. Most studies done on appendicitis were in wellequipped hospitals in urban areas of those countries, with relatively very few epidemiological studies on appendicitis have been conducted in rural high altitude of south Asian population.
There is very few or not at all research data concerning the monthly variation of acute appendicitis presenting in high altitude in Nepal, which geographic and climatic structure differ. The objective of this study is to observe the incidence of appendicitis variation with months of the year in such altitude region of Nepal.

\section{MATERIALS AND METHOD}

The cross sectional retrospective study was done in the Karnali Academy of Health Sciences, Jumla situated at the altitude above $2500 \mathrm{~m}$ from sea level. The approval was taken from IRC [Institutional Review Committee] of Karnali Academy of Health Sciences. The data were retrieved from the hospital record book of Operation Theater (OT) that included age, gender and ethnicity, month of the appendectomy performed, pre-operative clinical presentation and operative findings. The period of study was from July 2014 to March 2020. The appendectomies were performed both by open and laparoscopic techniques. The humidity, rainfall and temperature data were retrieved from the department of Hydrology and Meteorology, Surkhet Branch.

Inclusion criteria: All the appendicitis, clinically suspected and appendectomy performed were included in the study. Only the gross macroscopic findings of appendicitis during appendectomy such as congested vessels with reactive peritoneal fluids, abscess around the wall of appendix, fecolith, 
perforated tip and body of appendix were only included.

Exclusion criteria: All the patients with appendicitis and appendicular lump treated with conservative method were excluded from the study. Normal appendixes were also excluded. The data were entered in Excel software, descriptive analysis were done with SPSS 16 Versions.

\section{RESULTS}

Total of 119 cases of appendectomy performed during 5 years period, from June 2014 to March 2020, in the surgery department of karnali academy of health sciences, Jumla were recorded. The mean age at was $27 \pm 13.75$ years. There were $53.78 \%$ female $(n, 64)$ and male $46.21 \%(n, 55)$ patients. The months in which the highest appendectomy executed were July/August/September and February with 16\%, 13.4\%, $12.6 \%$ and $13.4 \%$ respectively. The lowest incidence was $1.7 \%$ in the month of April along with May.

The lowest age at appendectomy in our study was 8 years. The highest age was 74 years. At age group 20-29 years was found to have highest percentage of appendicitis 29.4\%, compared to other age group of same interval. The lowest number of appendicitis was 2.5\% above 60 years. Ethnicity wise, high cast were found to have $78.1 \%$ of appendicitis, with female $53.3 \%$.
Table:1 Characteristic features of the patients

\begin{tabular}{|l|l|l|l|}
\hline Characteristics & \multicolumn{2}{|c|}{ Frequency(N) } & \multicolumn{1}{l|}{ Total } \\
\hline 1$)$ Age & Male & Female & \\
\hline$<10$ & $2(40)$ & $3(60)$ & $5(4.2)$ \\
\hline $10-19$ & $11(36)$. & $19(63.3)$ & $30(25.2)$ \\
\hline $20-29$ & $15(42.9$ & $20(57.1)$ & $35(29.4)$ \\
\hline $30-39$ & $8(50)$ & $8(50)$ & $16(13.4)$ \\
\hline $40-49$ & $15(62.5)$ & $9(37.5)$ & $24(20.2)$ \\
\hline $50-59$ & $2(33.3)$ & $4(66.7)$ & $6(5.0)$ \\
\hline$>60$ & $2(66.7)$ & $1(33.3)$ & $3(2.5)$ \\
\hline Total & $55(46.2)$ & $64(53.7)$ & $119(100)$ \\
\hline 2)Ethnicity & & & \\
\hline Janjati & $4(46.2)$ & $6(53.8)$ & $10(8.4)$ \\
\hline High cast & $43(46.7)$ & $50(53.3)$ & $93(78.1)$ \\
\hline Low cast & $7(40)$ & $8(60)$ & $15(12)$ \\
\hline Terai cast & $1(100)$ & $0(0)$ & $1(0.84)$ \\
\hline Total & $55(46.1)$ & $64(53.7)$ & $119(100)$ \\
\hline 3)Mean (years) & & & $27 \pm 13.75$ \\
\hline 4)Lowest age & & & 8 year \\
\hline 5)Highest age & & & 76 year \\
\hline
\end{tabular}

Table 2: Showing the distribution of appendicitis in months

\begin{tabular}{|l|r|r|}
\hline Months & Freq.(N) & Percent(\%) \\
\hline January & 6 & 5.04 \\
\hline February & 16 & 13.4 \\
\hline March & 8 & 6.7 \\
\hline April & 2 & 1.7 \\
\hline May & 7 & 5.9 \\
\hline June & 5 & 4.2 \\
\hline July & 19 & 16 \\
\hline August & 16 & 13.4 \\
\hline September & 15 & 12.6 \\
\hline October & 8 & 6.7 \\
\hline November & 6 & 5.0 \\
\hline December & 11 & 9.2 \\
\hline Total & 119 & 100.0 \\
\hline
\end{tabular}


Figure 1: Showing graph of appendicitis, humidity, rainfall and Temperature

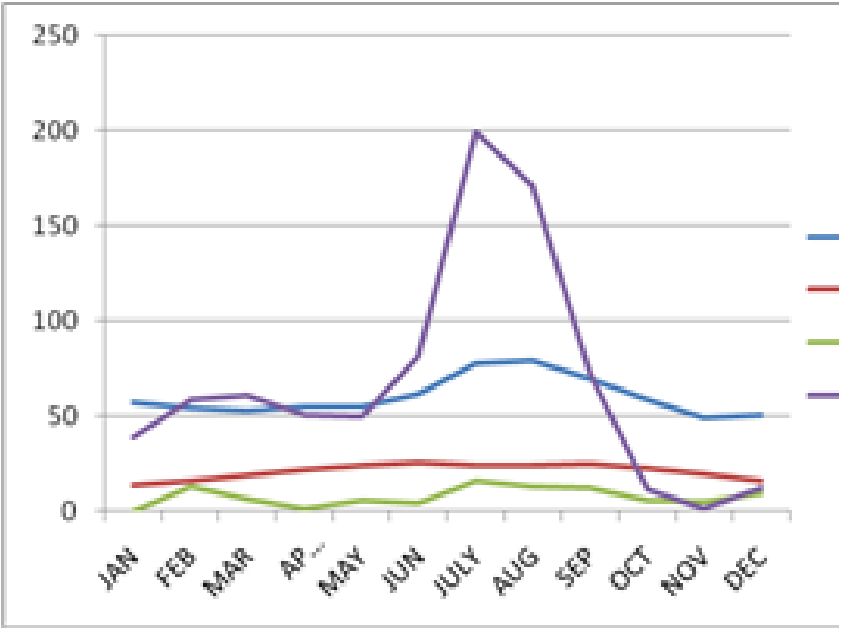

\section{DISCUSSION}

Appendicitis is a common disease present throughout the year, worldwide, ${ }^{1,2}$ but some particular months are associated with high incidences, although this vary from region to region. A study in India by Babita et al. over a decade noticed the maximum cases was seen in summer especially in August and minimum number were found in the winter. ${ }^{12}$ In a study conducted by Imre et al. in Finland showed the relation of acute appendicitis with the season with increased incidence in summer. ${ }^{13}$ In another study conducted at Taiwan by Lin et al. found the rates of appendicitis were $11.76 \%$ higher in the summer than in the winter months. ${ }^{14}$ Some authors from Canada and Tehran also reported the higher number of cases in summer. ${ }^{9,15}$

However there are some reports which showed the incidence of appendicitis high in spring. Ashley has reported an excess of cases during spring, implicating a high prevalence of viral infection during these months ${ }^{16}$. Similar reports have been shown in the study by Sanda et al. implicating intense sandstorm as cause in the Spring months, in the Arabian Peninsula ${ }^{7}$.

In our study, high number of appendicitis cases $16 \%, 13 \%$ and $12 \%$ were found in the month of
July, august, and September respectively which is consistent with results from different studies done by several authors at different work place or region..$^{8,17,18}$ The exact cause of increase appendicitis incidence was still in conjecture, however, many insidious factors might have been involved. The onset of the rainy season in this region started from July, the intensity of which increases toward the months of August and September is reflected on the data analysis of Jumla shown in Figure:1 [Courtesy by Metrological and forecasting Division, Surkhet Nepal]. On analyzing the pattern of rainfall and humidity, it has been revealed that rainfall and humidity is high in between July to September. The study by Gallerani et al. mentioned the possibility of various extrinsic factors such as humidity, rainfall, radiation, allergens, sun radiation, and viral and bacterial infection, role in the etiology of acute appendicitis. ${ }^{5}$ Others authors also have the same result. ${ }^{9,19}$ Khaevel et al. also reported the association of bacterial, viral and worm infestations in appendicitis, ${ }^{6}$ which apparently relates to seasons. Moreover, in the article "In the infectious disease outbreak in Nepal”, Karki et al. ${ }^{20}$ mentioned the most common infectious microbes, which numbers become high during rainy seasons, are bacteria, virus and worms. Thus, it is obvious that during rainy season especially from July to September the activity of microbes increase which are associated with the increase in the appendicitis incidence. Poor personal hygiene has also been reported to be the cause of appendicitis. ${ }^{21}$ This region mostly has low quality drinking water system, poor sanitation and poor hygiene which become more jeopardized by rainfall, and often the infectious disease prevail in these months, from July to September. From our study, more appendicitis incidence were observed in July to September, in which rainfall, humidity, bacterial, viral and worm infestations were obviously prevailed. Until and unless other factors are involved or the exact cause is still in conjecture, it could be inferred there must 
have an association of appendicitis incidence with the variation in the month in this altitude and environment.

In our study, the appendicitis is preponderance in the female with $53.7 \%$. The age group of $20-$ 29 years has the highest number 20(57.1\%) out of 35 females. In the ethnicity group, the high cast were predominant with $78.1 \%$ incidence in which female has $53.3 \%$ hold as shown in Table:1. The incidence of appendicitis is reported to be more in male with ratio ranging from 1.1-2.9:1, ${ }^{11,22}$ however, Shrestha et al. found female preponderance in the study. ${ }^{23}$

High incidence cases were observed in Feb/March besides the months of rainy and humid period. The exact cause is not well established, however, the significant changes in the air temperature and sun radiation may have role in incidence of appendicitis, as Khavael et al. ${ }^{19}$ mentioned. February and March being the transient time, illustrated in the Figure:1, of changing from cold to the warm with variable in radiation might have association in the appendicitis cases increase in this month of year.

We observed an inexplicable result regarding the lowest incidence of appendicitis with 1.7\% in the month of April/ May. The result is diverged from the previous published literature that mostly suggested increase appendicitis incidence in either summer or in spring with their particular involved etiogenesis factors. ${ }^{14,16}$ A systematic review of literature for the lowest incidence of appendicitis in seasonal variation was pursued, but none was found signifying lowest incidence in these months. On analyzing data in our study, it was found interesting that with lowest incidence of appendicitis there was lowest rainfall and humidity in the months April and May. It can be said or expected that people have lowest appendicitis incidence at altitude, especially in the month of April and May; however this need to be studied in further in large scale in randomized trial to gain the exact result to be generalized. The study was carried out with the small number of patients, mostly from Jumla district and it is a retrospective study with no histological report as this facility is not available in hour hospital. These are the limitation of the study. These study further carried with perspective method including other factors would help decrease the limitation of the study.

\section{CONCLUSION}

The incidence of appendicitis is high in the months from July to September with low incidence in the months of the April and May. This information could be useful to decrease the disease associated morbidity and mortality in those particular period of time, taking extra preventive measures.

Acknowledgment: I would like to extend my gratitude to all the staff of general surgery department and staffs from operating theater who directly and indirectly help in finding the records of the patients. My sincere thanks goes to Dr. Niresh Thapa for his suggestions and editing help in the article.

\section{REFERENCES}

1. Lee JH, Park YS, Choi JS. The epidemiology of appendicitis and appendectomy in South Korea; National Registry Data.J Epidemiol. 2010;20(2):97-105.

\section{CrossRef $|\underline{\text { Full Text }}| \underline{\text { Google Scholar }}$}

2. Turner JR. The Gastrointestinal tract. In: Kumar, Abbas, Fausto(eds). Robbins and Cotran pathologic basis of disease Saunders: Philadelphia; 2010:870-871publiashed in 2009[Elsiever]

3. Burkitt DP, Walker AR, Painter NS. Effect of dietary fiber on stools and 
transit-times, and its role in the causation of disease. Lancet 1972;30:1408-12. [PubMed] Available from https://doi.org/10.1016/s01406736(72)92974-1

4. Oldmeadow C, Wood I, Mengerson K, Visscher PM, Martin NG, Duffy DL. Investigation of the relationship between smoking and appendicitis in Australian twins. Ann Epidemiol 2008;18:631-6. ^

5. Gallerian M, Boari B, Anamia G,Cavallsuo G, Manfredini R. Seasonal variation in onset of acute appendicitis. Clin Ter.2006;157:123127 [PubMed|Full Text] PMID:16817501

6. Khaavel AA, Birkenfeldt RR. Nature of the relation of acute appendicitis morbidity to meterological and heliogeophysical factors. Vestn Khir Im II Grek. 1978;120:6770. [PubMed|][PMID:654016

7. Sanda RB, Zalloum M, El-Hossary M, Al-Rashid F, Ahmed O, Awad A, et al. Seasonal variation of appendicitis in northern Saudi Arabia. Ann Saudi Med 2008;28:140-1[PubMed|Full Text] https://dx.doi.org/10.5144\%2F02564947.2008.140a

8. A.S. Oguntola, M.L. Adeoti, T.A. Oyemolade. Appendicitis: Trends in incidence, age, sex, and seasonal variations in South-Western Nigeria. Ann Afr med J 2010;9:4 213-7 [FullText| https://doi.org/10.4103/1596$\underline{3519.70956}$
9. Noudeh YJ, Sadigh N, Ahmadnia AY. Epidemiologic features, seasonal variations and false positive rate of acute appendicitis in Shahr-e-Rey, Tehran. Int J Surg 2007:5:958.[PubMed] https://doi.org/10.1016/j.ijsu.2006.03. $\underline{009}$

10. Wolkomir A, Kornak P, Elsakr M, McGovern P. Seasonal variation of acute appendicitis: A 56-year study. South Med J 1987;80:95860.[PubMed|Full Text] https://doi.org/10.1097/00007611198708000-00006

11. Al Omran M, Mandani M, McLeod RS. Epidemiologic features of acute appendicitis in Ontario, Canada. Can J Surg 2003;46:263-8.[PubMed Full Text]

https://www.ncbi.nlm.nih.gov/pmc/art icles/PMC3211626/

12. Jangra B, Jangra MS, Rattan KN, Kadian YS. Seasonal and day of week variations in acute appendicitis in north Indian children. J Indian Assoc Pediatr Surg. 2013:18:42-43. https://doi.org/10.4103/0971$\underline{9261.107021 .}$.

13. Ilves I, Fagerström A, Herzig KH, Juvonen P, Miettinen P, Paajanen $\mathrm{H}$. Seasonal variations of acute appendicitis and nonspecific abdominal pain in Finland. World J Gastroenterol. 2014;20:4037-4042. https://doi.org/10.3748/wjg.v20.i14.40 $\underline{37}$

14. Lin KB, Lai KR, Yang NP, Chan CL, Liu YH, Pan RH, et al. Epidemiology and socioeconomic features of appendicitis in Taiwan: a 12-year 
population-based study. World J

Emerg Surg. 2015;10:42.[PubMed]

https://doi.org/10.1186/s13017-015-

0036-3

15. Al Omran M, Mandani M, McLeod RS. Epidemiologic features of acute appendicitis in Ontario, Canada. Can J Surg 2003;46:263-8.

https://www.ncbi.nlm.nih.gov/pmc/art icles/PMC3211626/

16. Ashley DJ. Observations on the epidemiology of appendicitis. Gut 1967;8:533-

8https://www.ncbi.nlm.nih.gov/pmc/ar $\underline{\text { ticles/PMC1552757/ }}$

17. Addis DG, Shaffer N, Fowler BS, Tauxe RV. The epidemiology of acute appendicitis and appendicectomy in the United States. Am J Epidemiol 1990;132:910-25.[PubMed] https://doi.org/10.1093/oxfordjournals .aje.a115734

18. Blomqvist $\mathrm{P}$, Ljung $\mathrm{H}$, Nyren $\mathrm{O}$, Ekbom A. Appendicectomy in Sweden 1989- 1993 assessed by the inpatient Registry. J Clin Epidemiol 1998;51:859-65. [PubMed|Full Text] https://doi.org/10.1016/s08954356(98)00065-1

19. Wei PL, Chen CS, Keller JJ, Lin HC. Monthly variation in acute appendicitis incidence: a 10-year nationwide population-based study. J

Surg Res. 2012;178:670-

676.[PubMed]

https://doi.org/10.1016/j.jss.2012.06.0 $\underline{34}$

20. R. karki. Management of disease outbreak in Nepal. The lancet,2015;386:9991:335336[DOI:1016/so140-6736(15)614039][Full Text]

21. Budhi Ida Bagus, Azka Rumaisha, Suwardi. The role of personal hygiene on non complicated pediatric appendicitis patients. Int Surg J.2018May;5(5):1614-1616[ DOI: http://dx.doi.org/10.18203/23492902.isj20181580]

22. Freud E, Pilpel D, Mares AJ. Acute appendicitis in childhood in the Negev region: Some epidemiological observations over an 11-year period (1973-1983). J Pediatr Gastroenterol Nutr 1988;7:680-4.[PubMed] https://doi.org/10.1097/00005176198809000-00010

23. Shrestha R , Ranabhat SR , Tiwari M1. Histopathologic analysis of appendectomy specimens. Journal of Pathology of Nepal (2012) Vol. 2, 21521[Full

Text] https://doi.org/10.3126/jpn.v2i3.6025 